Journal of Research in Technical Careers

May 2021, Vol. 5, No. 1

(C) Author(s)

\title{
The Value of Education Between Two African American Male Populations in a Rural Southern Community
}

\author{
Quentin R. Tyler, ${ }^{a}$ Stacy K. Vincent, ${ }^{b}$ Tiffany C. Monroe ${ }^{\mathrm{b}}$ \\ ${ }^{a}$ Michigan State University, ${ }^{b}$ University of Kentucky
}

\begin{abstract}
This study identified perceptions of education by low performing and college track African American males in a rural town in Southern Kentucky. Through the lens of Critical Race Theory and Symbolic Interactionism, the researchers explored how 16 young men value a secondary and postsecondary education. Selected by their administrator at two high schools, the males were identified as college track or low performing. The findings revealed that both groups identify racial relations as a barrier to educational achievement; however, college track males believed education would assist in overcoming racial divides. Additional findings highlight a difference in perception based upon the presence of a male role model, the home environment, and the felt need for survival. Based on the findings, recommendations include model programs and collaborations among societal groups within the young age; a need for male social programs that foster and encourage positivity throughout a young male's life; and the need for local resources to assist and encourage young African American males to pursue a postsecondary education.
\end{abstract}

Keywords: achievement, African American, males, education Attainment, rural

According to the National Center for Education Statistics, in 2016 African American males had a high school graduation rate of 73 percent; an improvement of four percent since the 2009 report (Kena, et al., 2016). However, in 2004, the U.S. Census reported high school graduation rates of African American males were behind their White counterparts by 10.6 percent; while in 2016, they were behind by an alarming 14 percent. In 2000, Hopkinsville, Kentucky reported slightly more than three thousand individuals had at least a bachelor's degree; 16 percent of the total population. Further, the national average for a bachelor's degree or higher was 24 percent. In Hopkinsville, less than three percent of African Americans have college degrees (U.S. Census Bureau, 2000).

Hopkinsville, located in Southwestern Kentucky has a population of 28,000, and known for prominent African American contributors in culture, politics, and education such as Ted Poston, a Black journalist in Roosevelt's cabinet; F. E. Whitney, the first 
African American pro term mayor in 1970; and Raymond Burse, current president of Kentucky State University and first Black to play rugby at Oxford University. In addition, Hopkinsville has numerous contemporary civic organizations with successful Black entrepreneurs and business people such as Pioneers Incorporated and the Modernettes; both are active in offering scholarships and outreach in their local communities. However, recently, Hopkinsville's strong reputation for excellence and perseverance has changed.

Although there is prominence in this small Kentucky town, a grueling barrier also exists. Kentuckyhealthfacts.org (2015) reports that Christian County, where Hopkinsville is located, has 2,566 drug arrests made per 100,000 citizens; whereas Kentucky has an average of 1,046 drug arrests per 100,00 residents, compared to the United States' average of 700 drug arrests per 100,000 residents. This cultural shift has had a great impact on the performance of the African American community which is now reflected in the schools. This is a similar plight for other African Americans in the United States.

Educational outcomes for African Americans, particularly men, are discouraging compared to other segments of the population. African American adolescent male students are at risk of facing a myriad of factors that can potentially affect their future (Smith, 2004; Ferguson, 2000). In almost every category of academic failure, African American male adolescents are disproportionately represented (Entwistle et al., 2004). African American boys are two to five times more likely to be suspended (and at a younger age) than white students (Noguera, 2003). African American boys are more likely to be classified or suffering from a learning disability, more likely to be placed in special education, and more likely to be absent from advanced-placement and honors courses (Harry et al., 2000).

When discussing education of African Americans, it is important to consider the works of W.E.B. Du Bois and Booker T. Washington. These African American educators of the past provide rich sources of ideas relevant to contemporary Black education, particularly because of the persistence of many problems of the past. W.E.B. Du Bois favored the classical education system while Booker T. Washington strongly promoted vocational education.

As racial violence, tension, and segregation increased, Du Bois viewed education as a process of teaching certain values: moderation, an avoidance of luxury, a concern for courtesy, a capacity to endure, and a nurturing love for beauty (Du Bois, 2001). Du Bois viewed education as a way to undermine the political system present in America. He called for great energy and initiative for African Americans controlling their own lives and for continued experimentation and innovation, while keeping education's fundamentally radical nature in view (Du Bois, 1903). Du Bois believed that African Americans must organize themselves as race-conscious people in order to win and exercise their freedom through education.

Booker T. Washington's ideas became reflective of a mentoring figure in his life, General Armstrong. General Armstrong believed that through a system of industrial education, a trained economically successful Black group would emerge, which would be significant and would inspire the masses of Blacks to seek better conditions (Gardner, 1975). He embraced the ideas of vocational and technical training for all Blacks with the 
career trajectories in the areas of Blacksmithing, locksmithing, machinery, mechanics, carpentry, brick masonry, plumbing, electricity, and artistry. Washington promoted industrial education over liberal arts education, mirroring his own education at the Hampton Institute. He also encouraged recently freed African Americans to learn a specific vocation in order to gain economic autonomy and status, which ultimately would lead to civil and political rights (Thorpe, 1969). Washington's central theme was that the academic status must be intelligently correlated with the social and industrial environment from which the students came and in which they probably would live and labor (Gardner, 1975). Although African American youth of today have not experienced institutional slavery, many of the conditions they must overcome are due to racial inequalities in their communities and education systems.

The $19^{\text {th }}$ century ideals of the W.E.B. Du Bois and Booker T. Washington bring relevance to current struggles, barriers and injustices when defining the racial perspectives of modern education. In pursuit of identifying contemporary minority perceptions toward education, Critical Race Theory (CRT) can be used as a tool to frame these understandings (Ladson-Billings, 1998). The overarching goal of CRT is to understand the oppressive aspects of society and work to examine social and cultural inequities and systems of intersecting power. At its formulation in the 1970s, CRT was an evaluative approach to the legal system that has expanded into evaluating all lived aspects among people of color (Delgado \& Stefanic, 2017). Eventually, in the 1990s, scholars applied it to education, as an approach to examine curriculum, instructional strategies, and assessment methods equitable for all students (Haskins \& Singh, 2015). Scholars ultimately aim to transform the relationship among race, racism, and power through CRT (Villenas \& Deyhle, 1999).

According to Dixson et al. (2017), there are five core principles of Critical Race Theory, in its application in education: 1) Racism is ordinary, not atypical; 2) Current bureaucratic systems advance the interests of elites; 3) Races are categories that society creates, manipulates, or retires when convenient for the dominant groups; 4) The dominant group characterize minorities at different times convenient to the needs of the majority; and 5) The act of storytelling is crucial for understanding how to create societal change.

Educational constructs of Critical Race Theory are based on: American school systems containing race and racism that are significant and endemic, education that is not a human right but a property right, along with race and property rights intersecting with high quality education (Dixson, et al., 2006). As Ladson-Billings (1998) asserted, if we look at the way that public education is currently configured, it is possible to see the ways that Critical Race Theory can be a powerful explanatory tool for the sustained inequity that people of color experience. Most importantly, young African American males develop meanings of education that are influenced by the construct of race.

In addition to Critical Race Theory, Symbolic Interactionism was used as a framework for this investigation. Symbolic Interactionism rests on three premises: (1) human beings act toward things on the basis of the meanings they ascribe to those things (2) the meanings of such things arises out of the social interaction that one has with others and society (3) meanings are created and changed through a process of interpretation (Blumer, 1969). Within these interactions, social objects are given 
symbolic value. This theory is appropriate because it provides a frame of reference for understanding the meaning attached to education and how these meanings influence behavior.

A recent study by Tolliver et al. (2020), recognized effects of high school African American dropouts on communities and investigated educational and social experiences that may lead to these outcomes. Tolliver (2020) focused on interrelated factors of family, peers, and community neighborhoods that could potentially shape educational perspectives. According to Henley (2019) male students were able to graduate high school at an average of 2.43 less risk factor reported than those that did not graduate. These drop out students reported more negative perceptions towards school and school environments.

While previous researchers focused directly on school resources and economic opportunities contributing to ways rural African Americans have lagged behind their urban counterparts, it is the researchers' assertion that the educational meanings in rural America shaped by racism and their environments that have affected current adolescent African Americans' educational perceptions and pursuits. Even though there is strong literature that supports the idea that African Americans believe education is important and vital to their community, there are arguments that contend otherwise. For example, Deroche (2020), posited that by virtue of being victims of a long history of racial oppression, African Americans have failed to develop a strong tradition valuing education. Moreover, Ogbu (1979) asserted African American parents tend to pass on to their children the belief that they will face the same prejudices they were previously faced with and will not be allowed to secure desirable jobs, regardless of their effort in school.

Clark (1991) contended that the academic achievement of African American male adolescents is critically influenced by the broad social environment, while Baker (2005) and Pickney (2000) stated specifically that the home life of African American male adolescents is quite different from that of their white counterparts because they lack resources for meeting educational needs. In addition, compared to parents and leaders in metropolitan communities, adults in rural areas may have different views about the purposes and aims of education and may link student success more directly to community and family needs than to educational and economic attainment (Lareau, 2002; Howley, 2001). Therefore, it is possible that parents and community leaders in rural areas may view successful youth outcomes more in terms of meeting family and community goals versus personal achievement goals.

\section{Purpose and Research Questions}

The purpose of this qualitative study was to explain the perceptions of educational obtainment from the lens of African American males of two identified domains. As a case study design, it is vital that this study seeks to determine the cultural characteristics of this group of people as well as differences that may exist between another group; thus leading to the following two research questions:

1. What are the perceptions African American males have on secondary education and postsecondary education? 
2. How do the two identified domains, low preforming and college track, differ in their perceptions, how are they similar?

\section{Methods}

A comparative qualitative research design was implemented to identify the perspectives of African American male students as related to the development and perception of education. More specifically, a qualitative case study served as the research approach for this study. Yin (2018) suggests that the term case refers to an event, an entity, an individual or even a unit of analysis. It is an empirical inquiry that investigates a contemporary phenomenon within its real-life context using multiple sources of evidence. The central aim of a case is to provide rich, holistic insights into people's views and actions, as well as the nature (e.g. sights, sounds) of the location they inhabit, through the collection of detailed observations and interviews (Yin, 2018). The participants comprised solely of secondary African America male youth, enrolled in secondary public schools and did not include parental or generational data. The subsets of the participants were identified as: (a) low performing student or (b) college track student.

Design Overview. The primary reasons for using qualitative research methods were to identify and understand the social phenomena of participants (Creswell \& Creswell, 2017). This was achieved by interviewing participants, interpreting meanings of participant's, their experiences, and establishing contextual frame of events and perceptions. Meaning was defined by details of actions, thoughts, feelings, beliefs and ideas (Merriam, 1988). In this study, the researchers sought to provide a description of the value of an education and identify patterns among the values. Qualitative methods that were used include focus groups and in-depth interviews. Validated data was collected by the flexibility of using combinations of techniques permitting the researcher to modify decision about data collection during the study.

Setting of Research. By gaining an understanding of the environments and community, the researcher sought to understand the human behavior and the framework of how thoughts, feelings and actions are developed (McMillian \& Schumacher, 2006). Moreover, McMillian and Schumacher (2006), determined that one cannot understand human behavior without understanding the framework within which subjects interpret their thoughts, feelings and actions. In 2015, the population of Christian County, where Hopkinsville is located, was 74,165. According to the Kentucky Center for Education \& Workforce Statistics from 2013-2014, 71.1\% if children in Christian Country qualified for free and reduced lunch rate in 2013-2014, $12.8 \%$ higher than the state of Kentucky. The Hopkinsville community is on the cultural, topography, and geographical edge of where the Appalachian region ends and the Mississippi Delta begins. A county with a rich history in production agriculture and nearby military base, Fort Campbell, serves as a safe haven for African Americans in Western Kentucky. 
Participant Selection. Because the purpose of this study was to identify perceptions of education by low performing and college track African American Males, the subjects were enrolled in the 9th, 10th, $11^{\text {th }}$, or 12th grades at one of the two public schools within the community. School administrators conducted the initial selection of participants based on the following criteria: (a) $9^{\text {th }}-12^{\text {th }}$ grades, (b) discipline records, (c) GPA, (d) extracurricular activities. Based on the measures, school administrators classified the participants as college track or low performing group dynamic. This preliminary process involved interviews of four total focus groups - two from each school, representing the two labeled group dynamics. Each focus group interview lasted between 1.5 to 2 hours in length. After focus group interviews, the researcher selected participants based on availability for an in-depth interview to further capture rich and extensive information. Some participants were contacted for a second interview for points of clarity. All participants provided school and parental consent, and confidentiality agreements. The researchers obtained IRB approval.

Data Collection. The researchers used six forms of data, as recommended by Yin (2018): documentation, archival records, interviews, direct observations, participant observations, and physical artifacts. All data were collected through face-to-face interactions with the participants and the exploration of performance/archival data provided by the local school administration. The face-to-face interviews provided information that assist in explaining the human experience (Moustakas, 1994). In order to efficiently manage mounds of linguistic data, an electronic system was used to retrieve and code data in one place. Followed by a data analysis software package (NVIVO 8.0) to classify, sort, and arrange information, allowing more time to explore trends, build and test theories, and ultimately arrive at answers to questions.

Focus Groups. Rather than individuals being interviewed alone, focus groups are multiple people that are purposefully sampled for interviewing (McMillian \& Shumacher, 2006). The encouragement of social environments by in-depth interviewers creates interactions by members of the group which increased the quality and richness of data. For example, group members can restate or critique questions, offer feedback on the questions and categories.

Four focus groups allowed exploration of student narratives on race that can be related to the Critical Race Theory (CRT). Critical Race Theory brings attention to pervasive racism, discrimination, and inequality of minority populations. By using the frame of CRT, data set richness of student stories can unveil and explain perceptions toward education by African American men. The selected groups contained 3-5 participants, which is identified to be within a range of comfortability for focus group participation (McMillian \& Shumacher, 2006). Each school had one college track group and one low performing group (see Table 1). 
Table 1. Focus Group Participants.

\begin{tabular}{lcc}
\hline School & College Track & Low Performing \\
\hline School A & 4 & 3 \\
School B & 5 & 4 \\
\hline Sub Total & 9 & 7 \\
\hline Total & & 16
\end{tabular}

One-on-One In-Depth Interviews. Following the focus group interviews, the researchers engaged in individual face-to-face interviews. This form of interviewing is communicated in open response questioning to obtain participant meanings, conceptions of meaning, and rich descriptions of important life events (McMillan \& Schumacher, 2006). Robust dialog was encouraged by the empowerment of both interviewee and interviewer. The interviewer used clarifying and follow-up questions to further understand and explain the lived experiences. Some participants did not feel comfortable discussing their viewpoints outside of the group or were not available to participate due to a variety of reasons. Most of these interviews took place after the school hour at diverse locations (i.e. school parking lot, homes, fast food restaurants, etc.)

The interviewer asked general discussion; broad, non-judgmental, open-ended questions. For example, "I would like to ask you what type of education you believe is successful in this community." Table 2 identifies the total number of participants engaged in the individual face-to-face interviews.

Table 2. One-on-One In-Depth Interview Participants.

\begin{tabular}{lcc}
\hline School & College Track & Low Performing \\
\hline Christian County & 1 & 3 \\
Hopkinsville High & 4 & 2 \\
\hline Sub Total & 5 & 5 \\
\hline Total & & 10
\end{tabular}

Reflexivity, Trustworthiness, and the Coding Process. The research team realizes that previously lived experiences play a role in the facilitation and interpretation of the study. In order to mitigate the effect that preconceptions can have on the research process, the team acknowledged personal biases in two forms of bracketing: a) research assumptions and b) hermeneutic (Fischer, 2009) throughout the research process. At the time of the study, one member of the team had over ten years of experience in research within the context of multiculturalism and underserved youth populations. Another member was an African American male with a notable reputation in diversity and inclusion. The final member identified as a biracial (Black/White) female who was beginning her scholarship in the area of multiculturalism. All three scholars had childhood homes in rural communities similar to Hopkinsville.

To assist in the trustworthiness of the participants' responses, one team member conducted all interviews while other team members took field notes and direct 
observations. Follow-up interviews provided opportunities for member checking and to confirm triangulation between all interviews. Between interviews, the team would reflect through a reflexive journal and through peer debriefing. All interviews were recorded and later transcribed for coding and interpretation. All transcriptions, direct observations, and field notes were coded through the lens of CRT. The team first established specific primary codes through specific chunks of text and as the study continued, the research team engaged in revising codes followed by the naming of codes to create themes. Finally, the research team engaged in a series of code checking, followed by code revisions (Denzin \& Lincoln, 2011).

Description of the Focus Groups. In order to have an understanding of each focus group, by their enrolled high school, the researchers provided identifiers to assist in developing a base for understanding the findings. At each focus group, the students began explaining what education means to them. The participants' brief explanation allows the researchers to gain insight and assist in developing questions for the individual interviews.

School A Focus Groups. College track students. The focus group participants consisted of four junior African American males. Two students were vocal and had consistent eye contact and the other two were also receptive but remained reserved. In order to engage the reserved students, direct questions were asked to assist in allowing them to feel included. Below are general responses by the participants of the college track focus group that reveal their perception of what an education means to them:

- "Education is very important in future, good job, work towards a craft."

- "Purpose or your future, work for your future."

- "New Technology, education, being adults, knowing what job you can do."

- "Going to college."

Low performing students. Two-freshman and one-sophomore status African American males selected by their principal made up the participants placed in the low performing focus group. Cell phones and outdoor stimuli visible from classroom windows distracted these students. After introductions and gaining familiarity the researchers asked the question, "What does an education mean to you?" The participants responded with comments along the realm of:

- "An education means everything."

- "An education means not stuck on the streets."

- "An education means something you have to have."

School B Focus Groups. College track students. Participants identified for the college track focus group played sports, one of which was signed to a major collegiate football program following graduation. They were encouraged by administration to greet the interviewer with a handshake and preceded with the interview process. The participants had collective ideas about education. They felt that education was a way to experience a different life and reach their goals. Below are additional responses: 
- "An education means another world."

- "I think as education means more opportunities to better life."

- "To get money you need an education."

Low performing students. The participants identified as low performing were members of the school's football program. The group collectively expressed an importance toward education but had much dialog centered on gang and drug activity. Moreover, the focus group participants felt that the meaning of education was representative of the life experiences they had to overcome. Some of these viewpoints were expressed as:

- "Education means you prevail over anything, dad dropped out of high school, mom legally blind."

- "Education means having an education."

- "Education means you don't have to feel second."

\section{Findings}

Comparative methodologies within the realm of case study design were used to identify similarities and difference between the two populations of students. After categorizing the open codes, themes began to emerge from both the college track and low performing participants, connections were established between education, opportunity (for college track students), race and the provider role.

College Track. All college track students were aware of racism and included this theme in majority of responses. Overall, they viewed education as a tool to break barriers established by racism. All themes present in relation to perceptions of education include: providing, responsibility, opportunity, and race. To best describe the dynamic of the college track participants, the lead researcher noted in their journal after the first meeting with one of the focus groups that "the young men entered the room with a level of confidence and swagger. They were proud of the organizations and athletic teams they were apart of and immediately wanted me to know."

College track: Providing. In this study the participants mentioned that stable employment and purpose for the future can be achieve with education. Fathers of some of the participants were out of either work or long term unemployed. These conditions provided insight into the importance of being able to provide for a family by having a career and not just a job. One focus group participant stated, "You have to work, provide for your family." Another individual from the same group stated, "Getting an education is being equipped with tools such as an education to provide for those who you are responsible for." The researchers noted acts of passion when the participants would spoke about this importance. One participant consistently hit is fist into his palm in repetition when he described the necessary need to help his extended family by furthering his education.

Although providing for your family is one interpretation, providing also took on a context of stepping into a mentality of manhood. The college track participants explained 
how being a provider was at the forefront in what it meant to be a man. They felt that in order to be a man, it was important to provide for your family as well as for yourself. Throughout the study, employment was mentioned among the college track participants. These participants showed evidence that they understood the importance of providing for their families despite the difficulty of the labor market their fathers were currently experiencing. For example, one participant stated, "To be a man, you have to work, be a man, and provide for your family." Another participant passionately stated, "Part of being a man is making ends meet, and getting an education is being equipped with tools such as an education to provide." To further support this idea of manhood, another participant noted "A man does what he has to do to provide, whether for himself or his family, to provide means doing whatever it takes to provide for your family. Sometimes sacrificing the time to obtain an education is necessary to provide."

During a home visit, the researchers recall an interview with a participant at his home out in the country that was reflective of someone from a low-socioeconomic background. The young man, 16-years of age, stated how important an education for his future was and that he did not take school seriously until after the $9^{\text {th }}$ grade. He further explained that his living situations and his peers from his past neighborhood were motivators for improvement in his grades. He wanted a better life for him and his family and only believed the only route was an education.

College track: Responsibility. Responsibility was a theme identified in which the participants believed that education led them to take on a provider role. Throughout the focus group and individual interviews, the participants believed that part of being responsible was realizing the importance of education; handling business in and out of school; taking ownership for your actions - whether having children or being punished for a crime; and providing for your family. In individual interviews, two participants stated, "A man takes responsibility for actions and helps their family take responsibility of family's action" and "A man takes care of responsibilities and then be accountable for his actions." Opportunities to be responsible is apparent in Hopkinsville, yet they are accompanied with social and communal pressures. The City of Hopkinsville provides activities such as athletics and vocational education, which can provide opportunities to practice responsibility; however, crime, drugs and gang activity can derail a young person from scholastic and extracurricular responsibilities. Tolliver et al. (2020) found little evidence that resources in the community such as positive leaders and academic support systems did little to assist high school graduates. In order maintain this act of responsibility, when thinking of college track, the participants continued to note that they "must" take personal responsibility to complete class work, home chores, work requirements, extracurricular expectations, and other requirements for developing skills necessary to further their education. One participant tied responsibility and providing by saying, "A man takes responsibility for his action, then helps his family take responsibility of family's actions."

Responsibility is a burden, but it is also a motivator, the research team parked down the street from one participant's home located in one of the worst neighborhoods in Hopkinsville. The participant did not have a father in the household but the mother was active in his learning. His living situations were not the best and mirrored the rest of the 
houses in his neighborhood. The interview was conducted on the porch because it was isolated from his family and it allowed the lead researcher to observe the neighborhood settings. The participant would take time and think about all questions he answered instead of just giving an answer. In answering questions about his grades, the participant believed that he gets all good grades except for a $\mathrm{C}$ in math. He stated that his mother constantly reminds him about the importance of his grades subsequently causing him to mention that at times he feels that he lets her down and feels responsible when he receives bad grades.

College track: Opportunity. College track participants believe education means one can have an opportunity for a greater life. As previously stated, many of the participants had unemployed parents and desired to have a life better for themselves. But in order to establish a path toward a better life, the participants believed opportunities were limited for them as African Americans and it would take all of their resources to acknowledge and take advantage of opportunities when they present themselves. With the acknowledgement that opportunities were limited, one participant recognized that a higher education was the only way for opportunities to exist by saying, "In Hopkinsville, you might need a master's degree, an associate's is not enough."

Many of the participants believed the community's limited opportunities were due to the economy and that an education meant an opportunity to leave the community and pursue a location where more opportunities for advancement were present. The participants expressed an appreciation for the opportunities experienced but also noticed that education was a buffer against discrimination and that not all opportunities were available for them. Furthermore, the college track participants viewed an education as an opportunity to go to college and obtain a career with the opportunities for advancement. One participant linked opportunity and being able to provide by stating, "In Hopkinsville, it's harder here, less opportunities to work at becoming a man; more pressures to succeed. If you are not up to par for the minimal ops [opportunities], may not be able to provide." An additional comment by a participant linked obtaining additional education with opportunity for providing in the future. "Education means a whole lot... Can't really get a lot with a high school education... a basic job." Although some of the participants believed that opportunities gave them a path to leave the community, some had a different viewpoint. One student stated, "For me, I see a lot of people that has been here all their life. I feel it is my duty to take advantage of the opportunity to get an education so I can bring what I learned back to my community."

College track: Race. The presence of race and discrimination was never-ending throughout the interview protocols. The participants had an internal feeling and stigma that because they identified and were seen as Black men, postsecondary institutions would label them as troublemakers. To support their perception, the participants at one focus group stated with vigor...

- "Having a degree, you are not labeled as being ghetto, or a thug but first you have to grudge through the stereotypes you will face in college as a black man." 
- "If you're a Black person and you can get the degree, people will think you are successful because they will know the [racial] struggles you had to go through to earn that degree."

- "College is good for African Americans...society...way people talk about education, statistics of African Americans in education."

Participants felt racism was present in their community and schools. They also felt that many Blacks were not aware of opportunities because of their race. Dan stated, "I have noticed in my youth organizations, youth leadership, typically 30 students in a program... only 4 are Black. It is even lower if we look at who has a leadership role." Similarly, Supples and Smith (1995), found in three recent community assessments of rural communities that racism was a predominant theme. Coincidently, college track participants believed that many African Americans in their own community did not want them to succeed. One student stated, with support from his friends, "There is racism in Hopkinsville, not necessarily Black versus white, but Black versus Black. So many people don't want other Blacks to succeed and will put you down for trying to be educated or successful." These students felt that race played a role in their beliefs about education yet education gave them a sense of power as a Black man. The researchers mutually agreed within each reflective journal that the college track participants maintained a firm commitment toward their education, even to the point of stubbornness - potentially because of racism. To reiterate the researchers' conclusions, a participant stated, "As an African American male, to feel on top and to be an athlete on top, grades mean even more on top, respect."

Finally, parents were influential in seeing how societal pressures of race created difficulties. Participants identified as college track, seemed to have parents that used race as a motivator to pursue education to advance and to create an easier path for future generations. In an individual interview, one participant stated, "My father is a pro Black person, he really focuses on the Black man, Black man trying to make it in this economy and he tells me about these hard times and what he has been through and how the road will be easier for me than them. His influence has been good on me because I just don't want to be another statistic."

Low Performing. Participants identified as low performing shared similar themes to college track students; however, home environment played a larger role in the framework of their perceptions. The lead researcher noted that each of the young men's parents were high school dropouts and/or in jail. The lack of a father's presence in the home had participants' emphasizing a need to provide for someone in their family and were not always thinking about education. Themes voiced by the low performing participants included: survival, home environment, and opportunity by vocational education. The researchers noted that the two focus groups identified as low performing were the more vocal groups. All of the students knew the importance of college but the conversation gravitated toward topics they were more familiar with such as gangs and drugs.

Low performing: Survival. Like the college track participants, masculinity was focused on in the discussion of education; however, for the low performing focus groups, 
education was mentioned as a means of survival. Each participant felt that if they received an education, it was a success, yet the education may not come from an institution. A participant stated, "Education means you can prevail over anything, dad dropped out of high school, mom legally blind, an education means having an education." He associated an education with successfully overcoming obstacles that occur in life (i.e. a tool to survive challenges). This reoccurrence of survival theme occurred during an individual interview, when one of the participants stated, "An education is a requirement to make it in life. To have an education is an achievement."

Other participants thought an education was a reflection of whether things were ideal in life. For example, "How life is going." In order to transition from survival mode having an ideal lifestyle you must have an education. Among the low performing participants, an education as a term of survival is rooted in masculinity; thus, a way of "being a man" as one participant responded. The participants explained a new form of masculinity and education in Hopkinsville had been routed to one of "making quick fast money," "participating in gangs," "sleeping with numerous women," and engaging in random acts of violence to prove one's toughness.

Low Performing: Home environments. Participants were encouraged to obtain a high school diploma at home but lacked the expectation of a postsecondary education and recognized this as an option if they desired to continue higher education. In addition, many of the low performing participants did not know how much education their father had, nor had any discussions with their father or mother about their parents' education. One low performing participant stated, "A man is someone that has a kid and is there for their kid." Furthermore, the importance of a man being home was stated by a participant as, "a man does chores around the home, to be there for family." And in another situation, a participant associated a man with the way you are raised at home. Others felt that if you were raised by an unsuccessful man at home, you were likely to follow in the same footsteps.

Although, the researchers received comments such as, "If you got a deadbeat dad, chances are you going to be a deadbeat dad." It should be noted that most of the individual interviews with participants identified as low performing did not have a father present or had been absent for long periods of time. In one interview conducted with two low performing participants, a low performing student expressed emphasis on their current conditions for meanings of being a man and did not express education as a way to escape this new rooted masculinity. Additionally, many of the low performing parents were not involved in their sons' lives or simply hoped that their sons would change their behavior on their own. A low performing participant spoke briefly about his lack of father involvement, "Father didn't influence me, I influenced myself."

Low Performing: Opportunity by vocational education. The theme was not directly present with the low performing participants; however, they did recognize vocational education as a gateway for future employment and trade. Many of the low performing students liked the idea of working with their hands. They became aware of vocational/career in technical education through guidance counselors and teachers, while the college track participants learned about workforce education from parents or a close relative. Interestingly, the students did not view an education as an opportunity but felt a 
vocational education would result positively on their future. African American males are more likely to participate in vocational/career and technical education during their secondary education experience (Fletcher, 2014; Fletcher \& Zirkle, 2009; Gordon, 2009). Three focus areas for students to be prepared for careers or postsecondary education are: academics, occupational, and technical (Fletcher, 2014; Stone, 2013). Therefore, programs with emphasis in vocation may be an operable option for African American males (Fletcher, 2014; Fletcher \& Cox, 2012). There are, however, criticisms of vocational education for African Americans as being a funnel for jobs that have limited to no advancement (Fletcher, 2014; Gordon, 2009). Both participating schools offer the opportunity for student to receive vocational education at an off-campus career and technical center. Overall, the participants seem to have a disconnect that vocational education was a route to successful education transition.

\section{Conclusion and Recommendations}

This study sought to find out what particularly influences the educational perceptions of teenage African American males in a select rural community in Kentucky. Through focus groups and individual interviews, the results and recommendations offer an additional perspective that is directly aligned with solutions that can be transferred to similar communities throughout the south. With issues plaguing school systems and mass incarceration rates for black males, this is a new era, and a more delicate population that is seeing an upward surge in the diversity of our population that is relevant to Hopkinsville, the state of Kentucky, and the nation. Further, the findings in this study voice the need to take a proactive approach in a variety of areas such as creating diversity and cultural competence training in schools for students, teachers, and administrators, developing programs that focus on college and career readiness, incorporating diversity and cultural competence throughout the curriculum, increasing the diversity of teachers and administrators in the K-12 system, and implementing programs that target African American males early in elementary and middle schools that focus on positive racial identity, community development, and service-learning opportunities.

Interest in this study revolved around masculinity and education. In particular, a question was posed in identifying how rural African American men in this community viewed what it means to be a man and if this outlook affects their meanings of education. The college track students associated the idea of being a man with taking care of their family both emotionally and financially. Also, the image of a man was important among the college track students as well as being viewed as responsible in the community. Most importantly, the college track students always mentioned "Black" or associated their meanings of a man with being a Black man. Unfortunately, many of the low performing participants could not vocalize their ideas of being a man and appeared to be uncomfortable when asked to describe their meaning of a man. In fact, many of the participants were consistent in their views of describing a man among their peers in Hopkinsville. They felt that their peers believed a man to be tough, having negative views about school and education, selling drugs, and sleeping with a vast number of women, which conflicted with the meanings that they were taught by adult role models. 
Researchers suggest that possible solutions in dealing with masculinity can be addressed with increased presence of committed and successful African American male adults (Davis, 2003; Hopkins, 1997). Having successful African American adult men in the community and in educational environments are essential for enhancing African American men academic and social identity development. Furthermore, researchers contend that the increased presence of committed and successful Black male adults in educational environments is essential for enhancing African American male adolescents' academic and social development (Davis, 2003; Span, 2000). Programs are needed that are school affiliated with local African American churches, fraternities, and civic groups to offer support services and mentoring for African American men. In addition, mentoring programs that assign Black men as role models for young boys typically in elementary and middle schools have been established in many school districts. Also, professional Black men serve as teachers, aids, tutors, and reading partners for African American male adolescents needing academic support and guidance.

Organizing all male schools or classrooms requires resources but has impactful life-altering changes. Also, Alternative Afrocentric models of masculinity are also being proposed (Davis, 2003; Kunjufu, 2005) and used in manhood development programs and curricular for younger males. These models call for an overthrow of Western models of male socialization and a regrounding of African American male adolescents and men in new cultural awareness. African American immersion schools and curricula that stress African and African American history and culture are viewed as positive strategies in building self-esteem and self-confidence and promoting dispositions for learning (Davis, 2003; Ajirotutu, 2000). These schools embrace a new conception of masculinity that shifts from dominant ideas of male socialization to a cultural awareness grounded in the positive experiences and history of African people, particularly Black men.

Based upon the findings, the researchers believe that pre-college programs that focus on college and career readiness would have a positive effect on the educational perceptions of African American teenagers as long as the programs link males with mentors through service-learning projects that build community pride. The Jr. Minorities in Agriculture, Natural Resources, and Related Sciences Program targets middle and high school youth focusing on exposure, engagement, and leadership. And there have been academies established that target African American males at a young age, and teaching positive racial identity such as the Black Males Working (BMW) Academy in Lexington, Kentucky.

As the participants of this study spoke about racism as a barrier to educational achievement in their schools and communities, taking a proactive approach to diversity and the development of cultural competence by schools and community leaders creates a climate that is inclusive and welcoming to students, teachers, administrators, and community stakeholders. Further, diversity and cultural competence trainings will position teachers to be culturally aware, develop the skills to relate to African American male teenagers, and develop a unique understanding of the challenges in relation to masculinity and racial identity of African American males as well as students from other backgrounds. It is important to have ongoing trainings that put school teachers, students, administrators, and community stakeholders together to discuss issues relevant to their 
school and community. A discussion on the importance of diversity and ways to involve the parents in their teenager's lives would strengthen the community, the schools, and the aspirations of the young men.

Moreover, there is a need to recruit more African American males, that can relate to the students, as teachers. Many of the students in this study spoke on the importance of positive Black role models and their willingness to associate education with opportunity. Specifically, those in the low performing groups had parents that did not correlate education and opportunity. Therefore, it is placed on the teacher to not only relate the two, but to also have high expectations for the youth (Vincent et al., 2014). Nationally, Black males represent roughly 2 percent of all public school teachers which may be having an impact on lowered expectations and lower grades for Black students. Researchers have found that nonblack teachers have significantly lower educational expectations in secondary and postsecondary degree obtainment for Black students compared to their Black counterparts when evaluating the same students (Gershenson et al., 2016).

\section{Opportunities for Future Research}

In 2020, society witnessed the ugly truth of racism in our country and the injustice that exist among a variety of disciplines. For years, scholars have provided evidence and requested education to address the growing achievement gap between the racial dynamic of youth. The purpose and findings of this study exposed how familial and societal norms play a major role in the outlook and treatment of a young African American male's education. Sociological studies that further explore what a young man's perceived masculinity and identity serves as influencers toward the educational outlook and career obtainment. In addition, a follow-up study of where these individuals are now and explore if the perceived educational attainments were accurate. Finally, similar studies to explore if similar dynamics and societal influencers are occurring among other rural communities would further assist in theoretical, sociological, and educational research that can establish pedagogical programs that encourages the postsecondary education of African American males. Finally, similar studies to explore if similar dynamics and societal influencers are occurring among other rural communities would further assist in theoretical, sociological, and educational research that can establish pedagogical programs that encourages the postsecondary education of African American males.

\section{References}

Ajirotutu, D. P. C. (2000). African-centered schooling in theory and practice. Greenwood Publishing Group.

Baker, P. (2005). The impact of cultural biases on African American students' education: A review of research literature regarding race-based schooling. Education and Urban Society, 37(3), 243-256.

Blumer, H. (1969). Symbolic interactionism: Perspective and method. University California Press. 
Clark, M. (1991). Two new boys in Melbourne. In A. Daniel (Ed.), Social democracy and social science: Essays in Honor of Sol Encel (pp. 6-18). Longman Cheshire.

Creswell, J. W., \& Creswell, J. D. (2017). Research design: Qualitative, quantitative, and mixed methods approaches. SAGE Publications.

Davis, J. E. (2003). Early schooling and academic achievement of African American males. Urban Education, 38(5), 515-537.

Deroche, D. (2020). Does mentorship matter? The experiences of African Americans from low SES in science, technology, engineering, and mathematics (STEM) [Doctoral dissertation, Creighton University].

Delgado, R., \& Stefanic, J. (2017). Critical race theory: An introduction. (3rd ed.). University Press.

Denzin, N. K., \& Lincoln, Y. S. (2011). The SAGE handbook of qualitative research. SAGE Publications.

Dixson, A. D., Anderson, C. K. R., \& Donnor, J. K. (Eds.). (2017). Critical race theory in education: All God's children got a song. (2nd ed.). Routledge.

Dixson, A. D., Anderson, C. K. R., \& Donnor, J. K. (Eds.). (2006). Critical race theory in education: All God's children got a song. Taylor \& Francis.

Du Bois, W. E. B. (1903). The souls of black folk: Essays and sketches. A. G. McClurg.

Du Bois, W. E. B. (2001). The education of Black people: Ten critiques, 1906-1960. NYU Press.

Entwistle, N., Trait, H., \& McCune, V. (2000). Patterns of response to an approach to studying inventory across contrasting groups and contexts. European Journal of the Psychology of Education, 15(1), 33-48.

Ferguson, A. A. (2000). Bad boys: Public schools on the making of black masculinity: Law, meaning, and violence. University of Michigan Press.

Fischer, C. T. (2009). Bracketing in qualitative research: Conceptual and practical matters. Psychotherapy Research, 19(4), 583-590. https://doi.org/10.1080/10503300902798375

Fletcher, E. C. (2014). High school students' exposure to diversity in an urban teaching academy and their conceptions of its place in future practice. The Urban Review, 46(4), 597-619.

Fletcher, E. C., Jr., \& Cox, E. D. (2012). Exploring the meaning African American students ascribe to their participation in high school career academies and the challenges they experience. High School Journal, 96(1), 4-19.

Fletcher, E. C., Jr., \& Zirkle, C. (2009). The relationship of high school curriculum tracks to degree attainment and occupational earnings. Career and Technical Education Research, 34(2), 81-102.

Gardner, B. (1975). The educational contributions of Booker T. Washington. Journal of Negro Education, 44(4), 502-518.

Gershenson, S., Holt, S. B., \& Papageorge, N. W. (2016). Who believes in me? The effect of student-teacher demographic match on teacher expectations. Economics of Education Review, 100(52). 209-224. http://doi:10.1016/j.econedurev.2016.03.002

Gordon, H. R. D. (2009). Identification of selected factors that impact the preparation of CTE teachers. Online Journal for Workforce Education and Development, 3(4), 4-10.

Harry, B., Kingner, J., \& Moore, R. (2000). Of rocks and soft places: Using qualitative methods to investigate the processes that result in disproportionately. Conference paper presented at the Minority Issues in Special Education, Harvard University.

Haskins, N., \& Singh, A. (2015). Critical race theory and counselor education pedagogy: Creating equitable training. Counselor Education \& Supervision, 54(4), 288-301. https://doi.org/10.1002/ceas.12027. 
Henley, H. O. (2019). Exploring the strategies educational leaders use to improve the graduation rate of African American students in alternative high schools [Doctoral dissertation, Colorado Technical University].

Hopkins, R. (1997). Educating Black males: Critical lessons in schooling, community, and power. SUNY Press.

Howley, C. (2001). The rural school bus ride in five states. The Rural School and Community Trust. https://www.ruraledu.org/articles.php?id=2139

Kena, G., Hussar W., McFarland J., de Brey C., Musu-Gillette, L., Wang, X., Zhang, J., Rathbun, A., Flicker, S., Diliberti M., Barmer, A., Bullock Mann, F., \& Dunlop Velez, E. (2016). The condition of education 2016 (NCES 2016-144). U.S. Department of Education, National Center for Education Statistics. Washington, DC. http://nces.ed.gov/pubsearch

Kentucky Center for Education and Workforce Statistics (2015). Christian County profile update. Frankfort. http://kentuckyhealthfacts.org

Kunjufu, J. (2005). Critical issues in educating African American youth. African American Images

Ladson-Billings, G. (1998). Just what is critical race theory and what's it doing in a nice field like education? International Journal of Qualitative Studies in Education, 11(1), 7-24

Lareau, A. (2002). Invisible inequality: Social class and childrearing in Black families and White families. American Sociological Review, 61(3), 747-776

McMillan, J. H., \& Schumacher, S. (2006). Research in education: Evidence based inquiry (6th ed.). Pearson.

Merriam, S. B. (1988). Case study research in education: A qualitative approach. JosseyBass.

Moustakas, C. (1994). Phenomenological research methods. SAGE Publications.

Noguera, P. A. (2003). City schools and the American dream: Reclaiming the promise of public education. Teachers College Press.

Ogbu, J. U. (1979). Minority education and caste: The American system in cross-cultural perspective. Crisis, 86(1), 17-21.

Smith, M. (2004). Defining the outcomes of teacher education: What's social justice got to do with it? Asia-Pacific Journal of Teacher Education, 32(3), 193-212.

Span, C. (2000). Black schools or Black children. Black males: Milwaukee and immersion schools. In M. C. Brown \& J. E. Davis (Eds), Black sons to mothers: Compliments, critiques, and challenges for cultural workers in education (pp. 135-153). Peter Lang.

Stone, J. R., III. (2013). If programs of study are the solution, what is the problem? International Journal of Educational Reform, 22(4), 294-312.

Supples, J. M., \& Smith, M. C. (1995). East and west of main street: Racism in rural America. Public Health Nursing, 12(4), 235-241.

Thorpe, E. E. (1969). The central theme of Black history. Seeman Printery.

Tolliver, D. V., Kacirek, K., \& Miller, M. T. (2020). Getting to and through college: African American adult men talk about increasing underrepresented student participation. College Student Journal, 53(4), 430-438.

U.S. Bureau of the Census. (2004). Census of Population and Housing. Washington, D.C

U.S. Bureau of the Census. (2000). Census of Population and Housing. Washington, D.C.

Villenas, S., \& Deyhle, D. (1999). Critical race theory and ethnographies challenging the stereotypes: Latino families, schooling, resilience and resistance. Curriculum Inquiry, 29(4), 413-445. 
Vincent, S. K., Kirby, A. T., Faulkner, P. E., \& Deeds, J. P. (2014). The evaluation of multicultural teaching concerns among pre-service teachers in the south. Journal of Agricultural Education, 55(1), 152-166. https://doi.org/10.5032/jae.2014.01152

Yin, R. K. (2018). Case study research and applications: Design and methods. SAGE Publications. 